\title{
Recent Progress in Metal-Organic Framework-Derived Nanostructures in the Removal of Volatile Organic Compounds
}

\author{
Deval Prasad Bhattarai ${ }^{1}\left(\mathbb{D}\right.$, Bishweshwar Pant $^{2,3}$, Jiwan Acharya ${ }^{2,3}$, Mira Park $2,3,4, *$ (D) \\ and Gunendra Prasad Ojha $2,3, *$ \\ 1 Department of Chemistry, Amrit Campus, Tribhuvan University, Kathmandu 44618, Nepal; \\ devalprasadbhattarai@gmail.com \\ 2 Carbon Composite Energy Nanomaterials Research Center, Woosuk University, 443 Samnye-ro, Samnye-eup, \\ Wanju-gun, Jeonju-si 55338, Korea; bisup@woosuk.ac.kr (B.P.); acharyajione@woosuk.ac.kr (J.A.) \\ 3 Woosuk Institute of Smart Convergence Life Care (WSCLC), Woosuk University, 443 Samnye-ro, Samnye-eup, \\ Wanju-gun, Jeonju-si 55338, Korea \\ 4 Department of Fire Disaster Prevention, Woosuk University, 443 Samnye-ro, Samnye-eup, Wanju-gun, \\ Jeonju-si 55338, Korea \\ * Correspondence: wonderfulmira@woosuk.ac.kr (M.P.); gpojha@woosuk.ac.kr (G.P.O.)
}

check for updates

Citation: Bhattarai, D.P.; Pant, B.; Acharya, J.; Park, M.; Ojha, G.P. Recent Progress in Metal-Organic Framework-Derived Nanostructures in the Removal of Volatile Organic Compounds. Molecules 2021, 26, 4948. https://doi.org/10.3390/ molecules 26164948

Academic Editor: Constantina Papatriantafyllopoulou

Received: 29 June 2021

Accepted: 10 August 2021

Published: 16 August 2021

Publisher's Note: MDPI stays neutral with regard to jurisdictional claims in published maps and institutional affiliations.

Copyright: (c) 2021 by the authors. Licensee MDPI, Basel, Switzerland. This article is an open access article distributed under the terms and conditions of the Creative Commons Attribution (CC BY) license (https:/ / creativecommons.org/licenses/by/ $4.0 /)$.

\begin{abstract}
Air is the most crucial and life-supporting input from nature to the living beings of the planet. The composition and quality of air significantly affects human health, either directly or indirectly. The presence of some industrially released gases, small particles of anthropogenic origin, and the deviation from the normal composition of air from the natural condition causes air pollution. Volatile organic compounds (VOCs) are common contaminants found as indoor as well as outdoor pollutants. Such pollutants represent acute or chronic health hazards to the human physiological system. In the environment, such polluted gases may cause chemical or photochemical smog, leading to detrimental effects such as acid rain, global warming, and environmental pollution through different routes. Ultimately, this will propagate into the food web and affect the ecosystem. In this context, the efficient removal of volatile organic compounds (VOCs) from the environment remains a major threat globally, yet satisfactory strategies and auxiliary materials are far from being in place. Metal-organic frameworks (MOFs) are known as an advanced class of porous coordination polymers, a smart material constructed from the covalently bonded and highly ordered arrangements of metal nodes and polyfunctional organic linkers with an organic-inorganic hybrid nature, high porosities and surface areas, abundant metal/organic species, large pore volumes, and elegant tunability of structures and compositions, making them ideal candidates for the removal of unwanted VOCs from air. This review summarizes the fundamentals of MOFs and VOCs with recent research progress on MOF-derived nanostructures/porous materials and their composites for the efficient removal of VOCs in the air, the remaining challenges, and some prospective for future efforts.
\end{abstract}

Keywords: VOCs; MOFs; nanomaterials

\section{Introduction to the Metal-Organic Framework}

Metal-organic frameworks are inorganic-organic porous crystalline materials with extremely high surface areas and significant chemical diversity. Metal ions or their clusters coordinated with organic ligands or linkers forming a one-, two-, or three-dimensional porous or void structure constitute a metal-organic framework (MOF) [1-3]. They are also called porous coordination polymers (PCPs) [4]. Ions of metal such as cobalt, copper, cadmium, zirconium, and iron, etc. can act as the central metal ion while organic moieties or compounds with carboxylates (e.g., benzene-1,3,5-tricarboxylate, 1,4-benzenedicarboxylate, etc.) or nitrogen-bearing compounds (e.g., bipyridines, imidazoles, azoles, etc.) can behave as the ligand (electron pair donor) or linker in MOF [5-7]. The bonding between metal ions (nodes) and linker could be oxygen coordinated or nitrogen coordinated. Various types of 
metal-organic frameworks are devised for different applications. For instance, Pang et al. developed "Quasi-Ce-MOF" as an electrocatalyst for the urea oxidation reaction [8]. In another work, Pang's team synthesized nitrogen-doped hexagonal NiCoO nanoplates from $\mathrm{Ni}-\mathrm{Co}-\mathrm{MOF}$ for the application in electrochemical energy storage [9]. Besides the fabrication of nanomaterials, MOFs have been exploited as a sacrificial precursor for the synthesis of carbon nanomaterials, metallic compounds, and their composites with a tunable and controllable nanoarchitecture for various applications [10]. Besides the aforementioned applications, MOF-based materials are also being used for catalysis [11].

In MOFs, the metal ions act like nodes to bind the arms of the organic ligand to form a repeating cage-like structure with a profound internal surface area (1000-10,000 $\left.\mathrm{m}^{2} / \mathrm{g}\right)$. Therefore, it can be regarded as a composition of metal nodes and organic linkers [12]. The effect of the cavity and pore size distribution (a few nanometers to several angstrom), functional groups, hydrophilic-hydrophobic properties and surface unsaturation impart significant applications of MOFs in various fields including the adsorption of gas molecules, volatile organic compounds, the catalytic degradation of various gaseous pollutants, etc. [13]. MOFs are structurally different from other traditional inorganic porous materials such as zeolite, mesoporous carbon $(2-50 \mathrm{~nm})$, and silica in terms of uniform pore structures, atomic level, structural uniformity, tunable porosity, extensive varieties and flexibility in network topology, dimension, and chemical functionality. MOF can be regarded as a synergistic feature of structure and compositions enhancing the high surface-to-volume ratio, low density, higher loading capacity and micro-reactor environment. Compared to inorganic microporous material such as zeolites, controlled architecture and pore functionalization impart flexible rational design for MOFs. In contrast to zeolite, MOFs differ in their construction having bridging organic ligands intact throughout the synthesis. The coordination number of metal ions dictates the number of binding ligands and their orientation influencing the shape, size, and orientation or pores. MOFs are different from the covalent organic framework (COFs) in the sense that the COFs are composed of light elements such as hydrogen, boron, carbon, nitrogen, and oxygen with extended structures.

Metal-organic frameworks have attracted much attention due to their versatile applications in the synthesis of porous nanomaterials, carbon materials, etc. applicable in various fields of research and technology such as supercapacitors, batteries and fuel cells, electro-catalytic reactions, water treatment, drug delivery, anti-angiogenesis and photodynamic therapy, catalysis, adsorption, removal of volatile organic compounds, oxygen reduction reaction, hydrogen evolution reaction, etc., and other possible fields [14-22]. Furthermore, open metal-organic frameworks have been widely used in separation chemistry, gas storage, and molecular recognition [23].

With the booming industrial development and urbanization, the level of air pollution has been alarmingly increasing over the world, inducing serious hazards to human health and the environment. The emission of a diverse level of pollutants such as nitrogen oxides (NOx), sulfur oxides (SOx), and carbon oxides (COx), volatile organic compounds (VOCs) into the environment can pose serious health problems and environmental implications as well as social ramifications. Among a list of airborne pollutants, VOCs are a class of remarkable pollutants [24-26]. Metal-organic frameworks have been used in the efficient removal of volatile organic compounds. The higher surface area, large pore volume, and specific gas adsorption potency of MOFs make them triumph over other common adsorbents for the removal of VOCs [27]. Post-fabrication changes of MOF can induce selective adsorption properties. MOFs can be executed for the synthesis of nanomaterials, which can be used for the removal of VOCs. Therefore, the synthesis of MOFs is crucial in the field of synthetic chemistry, separation chemistry, and the sensing of volatile organic compounds [28]. Metal-organic frameworks can be synthesized by any of the following methods:

a. Solvothermal or hydrothermal: in this process, crystals are allowed to grow smoothly over the course of hours to days from a hot solution.

b. Microwave-assisted solvothermal synthesis: in this method, microwaves can be used to nucleate MOF crystals rapidly from a solution. 
c. Chemical vapor deposition method: this is a solvent-free method for the synthesis of MOFs. In this method, initially, metal oxide precursor layers are deposited, followed by exposing to sublimed ligand molecules, which induces a phase transformation to the MOF crystal lattice.

Post-synthetic modification of MOFs:

Post-synthetic modification of MOFs helps to introduce some new sites with new chemical properties. It helps to increase the functionality of MOFs by reacting with metalorganic complexes with linkers. In this method, either the ligand or the metal ions are exchanged in pre-fabricated MOFs with a new ligand or metal ions by the exchange method [29]. The exchange is performed to tailor some specific functions onto the MOFs. For this purpose, the previously developed MOFs are washed with a solvent followed by soaking in a solution of new ligand or in a solution of new metal. The ligand exchange can be assisted by heating.

\section{Volatile Organic Compounds}

Volatile organic compounds are natural or synthetic, low-boiling organic compounds with smaller molecular mass and high vapor pressure existing at room temperature. VOCs may be polar or non-polar, aliphatic or aromatic, indoor- or outdoor-prevalent pollutants [30]. Naturally, VOCs are produced by plants, microorganisms, and animals. A large number of microbes can produce VOCs as a secondary metabolite during their growth, which are termed microbial VOCs [31,32]. Natural VOCs have their essential significance of protecting plants from stress, attracting insects for pollination and seed dispersal. Some VOCs, such as trans-anethole, estragole, eugenol, isoeugenol, camphor, thujones, etc., are the constituents of essential oil with therapeutic application [33,34]. Besides these, VOCs are produced from petrochemical industries, gasoline vehicles, solvent uses, dye and paint industries, building materials, cleaning products, and many synthetic compounds. VOCs may be aliphatic hydrocarbons or aromatic hydrocarbons and their derivatives. Usually, such VOCs are obtained as by-products from industry, agriculture, transportation, and day-to-day activities in households which potentiate either to vaporize or dissolve in water. Partially burnt fuels such as gasoline, diesel, petrol, etc. produces VOCs. Besides this, the uses of solvents, paints, wax, and some sorts of cosmetic products also produce VOCs [35-37].

\subsection{Sources and Effect of VOCs}

Many of the harmful VOCs are derived from anthropogenic activities such as the burning of fuels, leakage of harmful gases, industrial sewage discharge, e-waste, etc. [38]. Some of the common sources of harmful VOCs include formaldehyde, BTEX (benzene, toluene, ethylbenzene, and xylene), PAH (polycyclic aromatic hydrocarbon), styrene, tetrachloroethylene (used in dry cleaning), ethylene glycol, methylene chloride (used as paint stripper), 1,3-butadiene, 1,8-cineole, vinyl chloride, acetone, carbon tetrachloride, isopropylbenzene, undecane, etc. Combustion products of woods, fuels, diesel, gasolines, automobile emissions, and tobacco smoke also consist of VOCs. VOCs form a constituent in various commercial and household products such as many petroleum-based products, fumigants, moth repellents, carpets, paints, lacquers, varnishes, glues, perfumes, nail polishes, tobacco smokes, adhesives, dyes, rubber, plastics, and cleaners used in industries and manufacturing companies. VOCs are also present in personal care products such as perfumes, deodorants, lotions, and some pharmaceutical products [39,40].

Semi-volatile organic compounds (SVOCs) have relatively higher boiling points than VOCs and evaporate at a slow rate but can accumulate over a time. Some examples of semi-volatile organic compounds include chlorinated tris, fire retardants (PCBs, PBB), pesticides (DDT, chlordane), etc. In the global emission estimates, the major contribution of VOCs is biogenic sources [41].

Above a permissible level, VOCs can have acute or chronic effects on humans. Inhalation of VOCs in humans provides prompt absorption across the lungs, gastrointestinal tract, 
and skin. Short-term exposure to such chemicals is associated with headaches, irritability, depression, dizziness, allergies, asthma, difficulty with concentration, and irritation of delicate organs such as the skin, ears, eyes, nose, throat, etc. Long-term exposure to VOCs is likely to affect vital organs such as the liver, kidneys, nervous system, etc. Some VOCs can cause cancer to humans, even at low concentration. The extreme effect of such VOCs may lead to genetic disorders [42].

VOCs not only have an affect on humans but also equally affect the environment. Though VOCs tend to escape from the groundwater by evaporation, once they are dissolved in groundwater, they are more persistent. Furthermore, some VOCs are degraded by aquatic bacteria; still, some other VOCs are non-degradable and ultimately enter the food web or ecosystem. VOCs can form ground-level ozone or chemical smog and secondary organic aerosols (SOAs) by reacting with nitrogen oxides, which ultimately causes a detrimental effect on the environment. VOCs are one of the major sources of atmospheric photochemical reactions causing various environmental hazards [43].

\subsection{Classification of VOCs}

Not all compounds are equally volatile. The volatile compounds that evaporate faster are more hazardous and cause a more serious risk than others There is no clear demarcation for the categorization of volatile compounds, but the United States Environmental Protection Agency (EPA) has adopted World Health Organization (WHO) Guidelines to divide indoor organic pollutants into the following types:

\section{A. Very Volatile Organic Compounds (VVOCs):}

The boiling point of these compounds fall in the range of 0 to $50-100^{\circ} \mathrm{C}$. Some common examples are propane, butane, methyl chloride, etc.

B. Volatile Organic Compounds (VOCs):

The boiling point of these compounds fall in the range of $50-100$ to $240-260{ }^{\circ} \mathrm{C}$. Some common examples are formaldehyde, toluene, acetone, ethanol, isopropyl alcohol, hexanal, etc.

\section{Semi-Volatile Organic Compounds (SVOCs):}

The boiling point of these compounds fall in the range of $240-260$ to $380-400{ }^{\circ} \mathrm{C}$. Some common examples of such compounds are pesticides such as DDT, chlordane, phthalates, and fire retardants such as PCBs, PBBs, etc.

\subsection{Removal of VOCs}

The effective removal of harmful gases including volatile organic compounds is of significant importance for personal protection from being exposed to such hazardous compounds as well as environmental protection. In this context, the effective and efficient removal of volatile organic compounds from the environment is inevitable and has attracted a great deal of attention from researchers. Commonly used techniques for the removal of VOCs include thermal and catalytic oxidation, adsorption, condensation, bio-filtration, membrane separation, UV-oxidation, catalytic oxidation, and surface modification [44-46]. Some of the common methods for the removal of VOCs are given in Table 1. All measurement methods for VOCs are selective or no method is capable of measuring all VOCs. Therefore, researchers are investigating a cost-effective, efficient, and environmentally friendly technique with high sensitivity, selectivity, and specificity. Physical adsorption or chemical adsorption of gas molecules rely on the surface area, pore size (microporous, mesoporous, and macroporous), atomic coordination, and electron density (electron rich or electron deficit) of solid adsorbent. Highly porous materials explored for volatile organic compound adsorption are activated carbons, porous silica, carbon nanotubes, molecular sieves, and various kinds of zeolites where a major mode of gas entrapment is physical adsorption via van der Waals' forces [47]. Still, there is plenty of room to create specific adsorption sites on the adsorbent by surface the functionalization process [48]. For this 
purpose, a highly porous solid material with a rigid outfit with appropriate voids sufficient to lodge the organic moieties of a hydrophilic or lipophilic nature is essential. One such material could be metal-organic framework (MOF) or metal-organic framework-derived nanomaterials with profound surface areas. In terms of increasing the surface efficacy or decreasing the dead volume, a metal-organic framework-derived nanostructured material could be a highly desirable porous material for the removal of volatile organic compounds.

Table 1. Some volatile organic compounds, their sources, and common methods of removal.

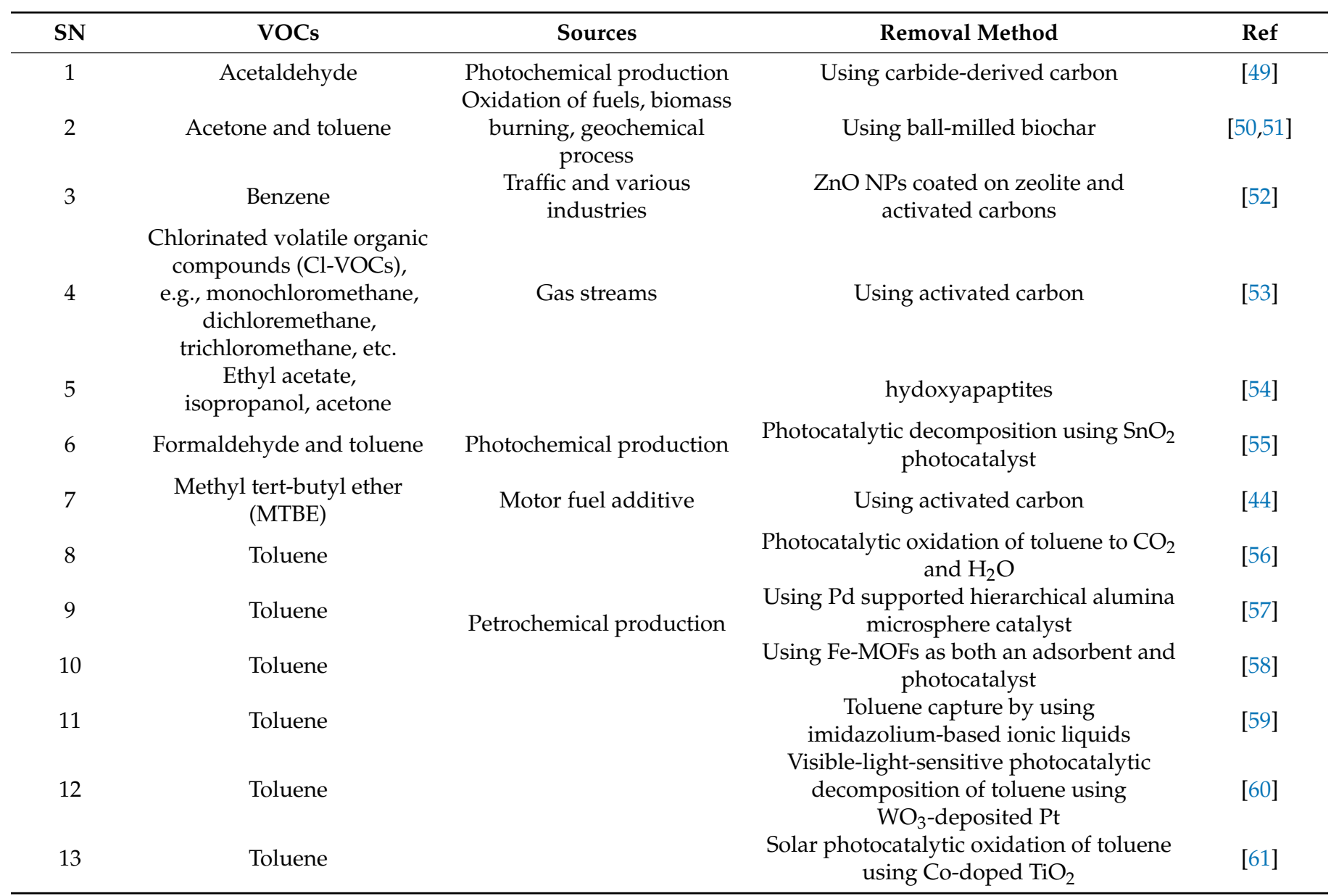

\section{Some Metal-Organic Frameworks:}

Some commonly used metal-organic framework are briefly discussed below.

A ZIF-8 is 2-methylimadizole zinc salt of general chemical formula $\mathrm{C}_{8} \mathrm{H}_{10} \mathrm{~N}_{4} \mathrm{Zn}$. The $\mathrm{ZIF-8}$ is $\mathrm{Zn}(\mathrm{MeIM})_{2}$. Here, MeIM is 2-methylimidazolate. The ZIF-8 is composed of zinc atom bonded with 2-methylimidazolate ligands with large cavities (11.4 $\AA$ ) and small pore (3.4 $\AA$ ) structures (Figure 1a [62]). The different SEM image of different ZIF structures [63] are shown in the Figure 2.

B Cu-BTC is copper benzene-1,3,5-tricarboxylate with a chemical formula of $\left[\mathrm{Cu}_{3}(\mathrm{btc})_{2}\right]$ or $\mathrm{C}_{16} \mathrm{H}_{6} \mathrm{Cu}_{3} \mathrm{O}_{12}$. Here, btc is 1,3,5-benzenetricarboxylate. It is commercially available. It consists of three distinct cages: one small octahedral cage with a pore window of $2.0 \AA$ and pore radius of $5.2 \AA$. Another larger cage is the cuboctahedral cage with a pore radius of $6.1 \AA$ connected by a pore aperture of $2.6 \AA$ radius (Figure $1 \mathrm{~b}$ ). 

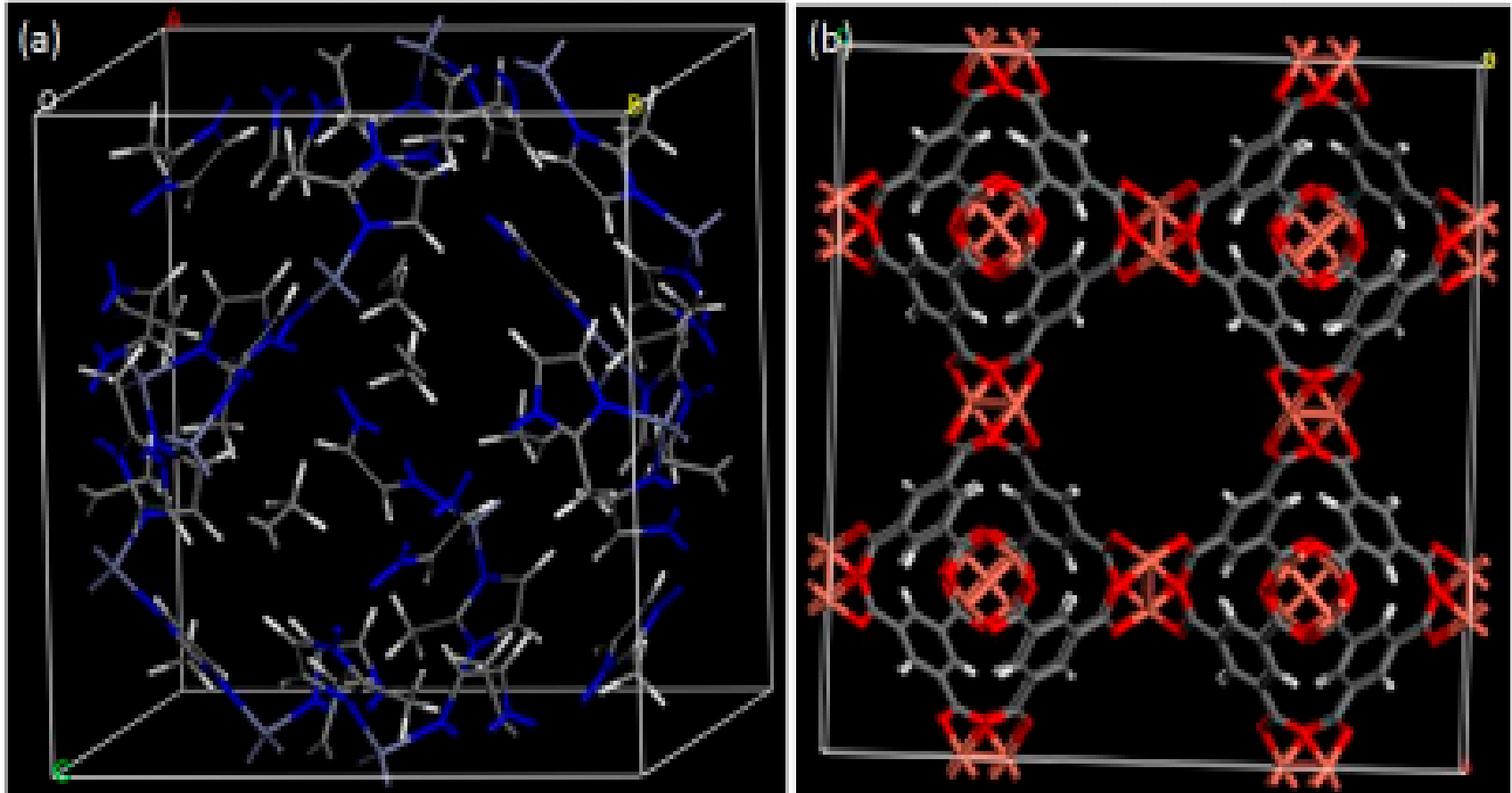

Figure 1. ZIF-8 (a) and Cu-BTC (b) obtained by modeling (adapted from Boudjema et al., 2019, with permission).
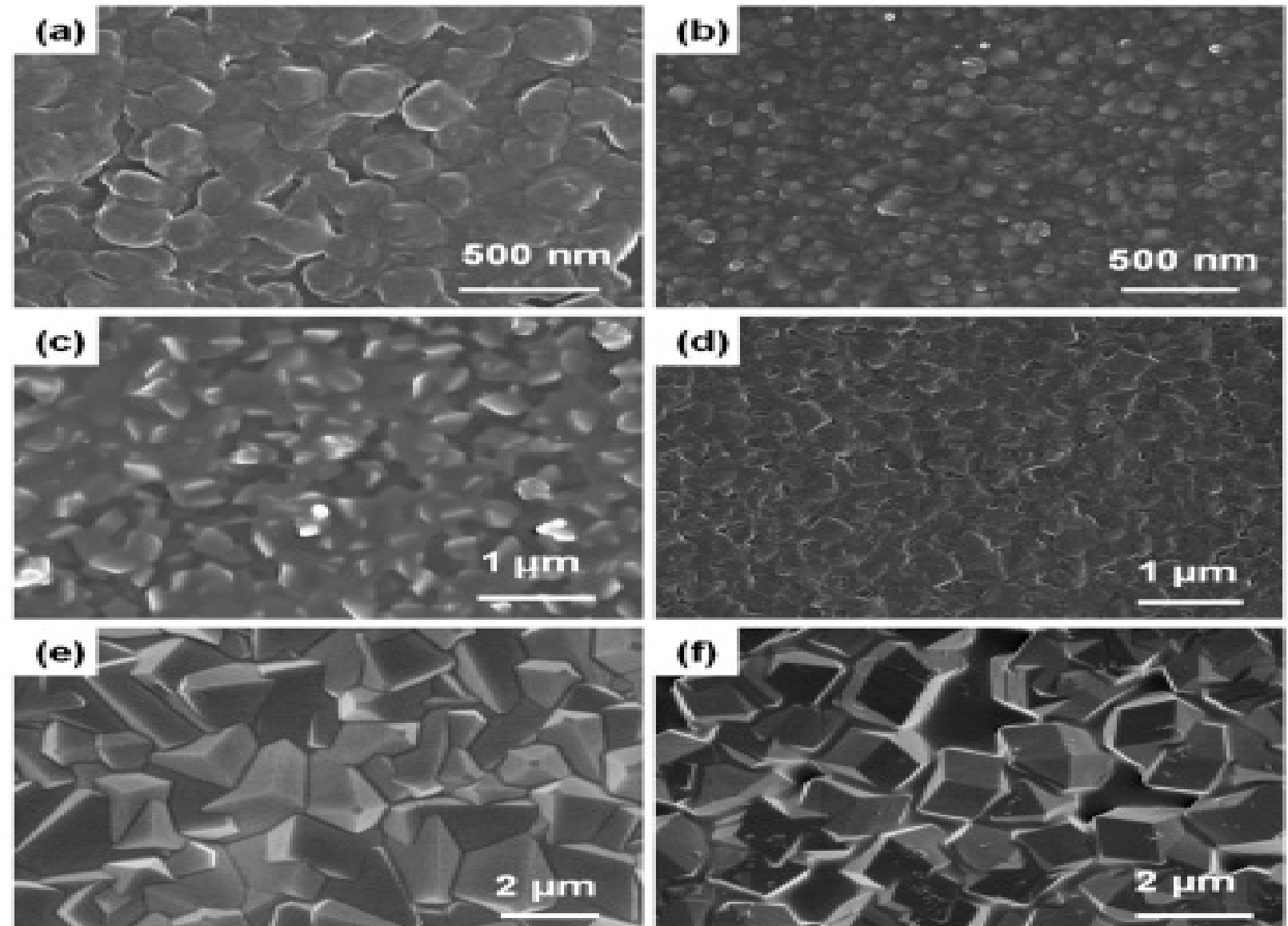

Figure 2. SEM image of ZIF thin films grown on $\mathrm{SiO}_{2}$ surface with ten growth cycles: (a) ZIF-7, (b) ZIF-8, (c) ZIF-9, (d) ZIF-65-Zn, (e) ZIF-67, and (f) ZIF-90 (adapted from Tu et al., 2015, with permission). 


\subsection{MOF-Derived Nanomaterials for the Removal of VOCs}

Nanomaterials are characterized by their high surface area, tunable morphology, and tailorable surface functionality. These days, nanomaterials are gaining superb interest in the field of research as well as in commerce due to their large surface area (aspect ratio); tunable shape, size, and structure; and easiness of fabrication with pronounced magnetic, optical, and electrical properties [64-66]. Various tools, techniques, and methods have been devised for the synthesis of desired nanomaterial outfits. The removal of VOCs using active catalyst at low cost, high activity with enhanced surface area is fascinating to researchers. Transition metal oxides, noble metal oxides, and zeolites are commonly used catalysts for the oxidation of VOCs [67]. Contrary to the high-cost noble metal oxide nanomaterials, transition metal oxides are benefitted by their excellent performance at low cost, higher thermal stability, and high natural reserve. Transition metal oxides have variable oxidation states in contrast to non-transition metal oxides, in general. Having such variable oxidation states are better suited for VOCs' sensing applications. For instance, in the presence of excessive reactive oxygen species (ROS) produced from ionizer, oxidative conversion of $\mathrm{Co}(\mathrm{II})$ to $\mathrm{Co}(\mathrm{III})$ is possible. The tetrahedral $\mathrm{Co}(\mathrm{II})$ having a $3 \mathrm{~d}^{7}$ configuration changes to less stable tetrahedral $3 \mathrm{~d}^{6}$ configuration. The reported ligand field stabilization energy (LFSE) for tetrahedral $3 \mathrm{~d}^{6}$ and $3 \mathrm{~d}^{7}$ are $0.6 \Delta_{\mathrm{T}}$ and $1.2 \Delta_{\mathrm{T}}$, respectively. The Co(III) species becomes favorable to the adsorption of VOCs, especially nitrogen and oxygen donor moieties [68]. Transition metals such as cobalt and manganese have variable oxidation states, which seems very suitable for the redox reaction and oxidation of volatile organic compounds [69]. For higher sensitivity, binary, ternary, or noble metal decorated metal oxides can be used. Furthermore, tuning of the shape, size, composition, surface area, doping level, and fabrication method can enhance the sensitivity performance. Besides these, carbon nanomaterials, nano-biochar, silica nanomaterials, etc. are also commonly used for the removal of VOCs [70-73]. Some of the commonly used nanomaterials for the removal of VOCs include graphene-based nanomaterials, mesoporous organosilica nanomaterials, carbon nanomaterials, etc. There are various methods for the preparation of nanomaterials including chemical methods, electrochemical methods, electrospinning methods, and so on [74-79]. However, the dire need of highly porous nanomaterials may not be addressed by such conventional methods. A new method for the synthesis of highly porous nanomaterials could be by using the metal-organic framework. These days, due to having a high surface area, adjustable aperture, and controllable calcination condition, versatile applications have highly increased an interest on MOFs [80]. Metal clusters as well as organic linkers (ligands), which are the part and parcels of metal-organic frameworks, can be executed for the fabrication of metal or metal oxide nanomaterials as well as carbon nanomaterials, respectively. The synergistic effect of nanoporous carbon wrapped metal or metal oxide nanomaterials can exhibit still more some advantages such as greater stability, dispersion of metal active sites, etc. [81,82]. In this context, the metal-organic framework seems to be a versatile precursor as well as a sacrificial template for the synthesis of porous nanomaterials such as oxides, carbides, chalcogenides, etc. [83]. The synthesis of MOFderived NMs is benefitted by their controllable compositions and tunable morphologies with affluent porosity endowed, with versatile applications in various fields including sensors and volatile organic compound removal. Zhang et al. reported that MOF-derived (Mn-MIL-100) porous $\mathrm{Mn}_{2} \mathrm{O}_{3}$ cubes displayed sound stability and high activity for the oxidation of carbon mono-oxide over its surface. This method of preparation benefitted from having a high quantity of surface active oxygen, a smaller particle size, and oxygen vacancies along with low temperature reduction behavior [84]. Sun et al. reported the preparation of $\mathrm{MnO}_{\mathrm{x}}$ by various methods such as thermal decomposition, pyrolysis of $\mathrm{MOFs}$, and co-precipitation. Among them, MOF-derived $\mathrm{MnO}_{\mathrm{x}}$ exhibited excellent catalytic activity of toluene, which could be attributed to the high surface defects [85]. In many cases, MOFs can be used as templates to develop NMs. The appropriate selection of metalorganic framework precursors with special morphologies under suitable experimental 
conditions can yield a material of desired morphology. Metal, metal oxides, metal sulfides, and other nanosized materials can be synthesized using a suitable nano-MOFs precursor.

MOFs themselves are a large source of carbon. Metal ions in connection with organic ligands in MOFs can be reduced to metallic composites by the carbothermal reduction process followed by acid etching of metal. The porosity retains its position in the products though the thermal treatment, which may change the pore size distribution within MOFs. MOF-derived porous carbon or carbon-metal porous material can be obtained by direct calcination of MOFs. However, porous carbon material can be prepared by intrusion of a secondary carbon source (e.g., phenolic resin, furfuryl alcohol, ethylenediamine, etc.) either by the wet chemical method or by the vapor phase method followed by carbonization in an inert atmosphere. Nitrogen-doped porous carbon material can be obtained either by the carbonization of nitrogen-rich MOFs (e.g., zeolite imidazolate framework, ZIF-8) or by carbonization of nitrogen-rich organic solution (e.g., dicyanamide) dispersed MOFs. Hetero-element (oxygen, phosphorus, nitrogen, etc.) doping can also be performed by soaking MOFs in organic solution rich in glycophosphine, triarylphosphine (for phosphorus), and dimethylsulphoxide (for sulfur). MOF-derived metal oxides can be obtained by treating MOFs in an excess of air, whereby organic linkers are decomposed, leaving behind metal oxides.

\subsection{Some Common VOCs and Their Removal}

Some common VOCs and their removal methods are briefly described below.

Removal of propane and butane:

Propane and butane are commonly used very volatile organic compounds. They are shipped as a liquefied gas and are commonly used for heating and cooking purpose. They are used as common heating fuels in households, heaters to warm garages, and as fuels used for barbecuing, gas grills, and camping lights. These volatile compounds are mostly released from their uses in grills, heaters, and camping lights. These are harmful substances to be inhaled. These gases can be removed by the oxidation process. For instance, propane is converted into water and carbon dioxide via the oxidative reaction. MOF-derived NMs have been used for its removal. Lin et al. synthesized $\mathrm{Co}_{3} \mathrm{O}_{4}$ nanoparticle-assembled micro-rods with Co-BTC (cobalt-1,3,5-benzenetricarboxylic acid) MOFs for the oxidation of propane. Lin et al. proposed the decomposition of propane as the following: two hydrogen atoms are deprotonated from propane and changes to propylene. Then, hydrogen attached to a singly bonded carbon atom is replaced by a hydroxyl group to form allyl alcohol, which is oxidized to ally acid and decomposes to carbon dioxide and water [86].

Removal of methyl chloride:

Methyl chloride is also called chloromethane. It is a colorless, flammable, and toxic gas commonly used in refrigeration and has applications in various industries. It is used as a solvent in petroleum refining, as a methylating and chlorinating agent in organic synthesis, as a propellant in polystyrene foam, and as a herbicide. Methyl chloride is typically present in paint removers, aerosol solvents, and flame retardant chemicals used in fire extinguishers. It is a prominent volatile compound and is prone to photochemical reaction. The inhalation of methyl chloride may cause dizziness and drowsiness depending upon the level of exposure. Kumar et al. synthesized non-activated biochar for the removal of methyl chloride [72]. The MOF-derived highly porous carbon materials could be useful for the removal of volatile organic compounds such as methyl chloride.

Removal of ethanol:

Ethanol is commonly called ethyl alcohol. Ethanol is typically used as in cleaners, sanitizers, laundry detergents, and dishwasher detergents. Ipadeola et al. [87] synthesized $\mathrm{Pd} / \mathrm{SnO}_{2} \mathrm{NPs}$ on MOF-derived carbon for the oxidation of ethanol. $\mathrm{Pd} / \mathrm{SnO}_{2} /$ metalorganic framework-derived carbon (MOFDC) exhibited a superior kinetic parameter in terms of the Tafel slope. This principle is also applicable for direct ethanol fuel cell. 


\section{Removal of methanol:}

Methanol is commonly called methyl alcohol. Wu et al. synthesized ultrafine Pt NPs and amorphous Ni supported on 3D-mesoporous carbon-derived Cu-MOF for the oxidation of methanol [88]. The carbon matrix lodged for profound dispersion of $\mathrm{Pt}$ NPs. The composite catalyst was also found to manifest an outstanding property for the reduction of nitrophenol.

Removal of formaldehyde:

Formaldehyde, also called methanol, is a common volatile organic compound. It is classified as a carcinogenic compound. It is present in molded plastics and coatings such as furniture polish. Nearly $40 \%$ formaldehyde is called formalin, which is commonly used in museum specimens. Formaldehyde is used to prepare resins for building materials, and coating for clothing fabrics and paper. It is commonly present in plastics, glues, lacquers, laminate flooring, plywood, fiberboard, particle board, etc. For the detection of formaldehyde, Zhang et al. synthesized $\mathrm{ZnO} / \mathrm{ZnCo}_{2} \mathrm{O}_{4}$ microsphere modified by catalytic palladium oxide nanoparticles via an MOF-template route. The microsphere exhibited a fast and higher response, better selectivity, and low detection limit (200 ppb) [89]. Wang et al. developed Janus AuNRs@ZnO@ZIF-8 NPs for the simultaneous detection and removal of formaldehyde (Figure 3a,b). Figure 4 shows the experimental setup for the $\mathrm{HCHO}$ detection.
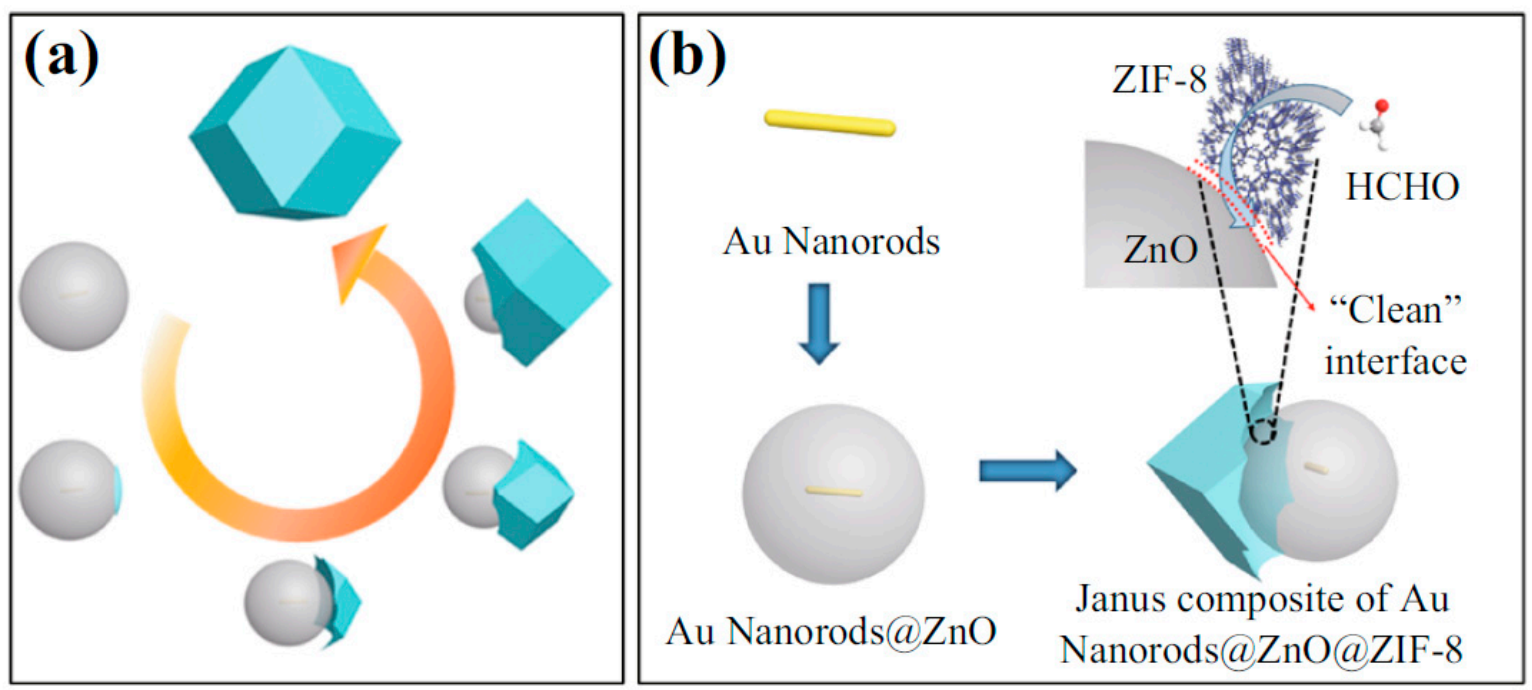

Figure 3. (a) Diagrammatic illustration of anisotropic synthesis of AuNRs@ZnO@ZIF-8; (b) selective detection of HCHO (adapted from Wang et al., with permission) [90]. 


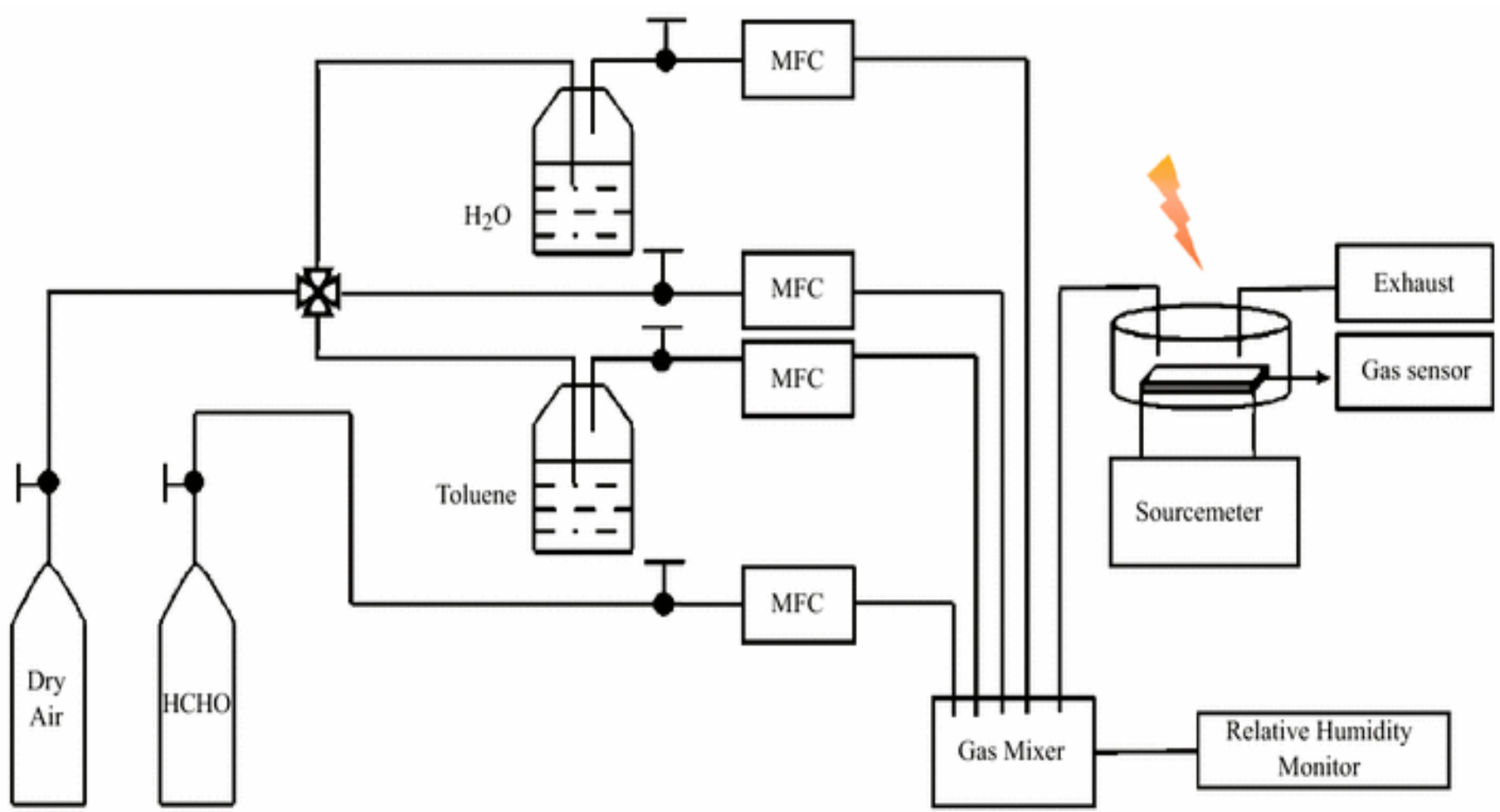

Figure 4. Schematic diagram for the detection of formaldehyde using sensing setup (adapted from Wang et al., with permission [90].

Removal of formic acid:

Formic acid, also called methanoic acid, can be removed by the catalytic decomposition method. Wang et al. developed N-doped C-anchored Pd NPs by the wet chemical method using MOF (ZIF-8) as a precursor. The porous structure of carbon exhibited a high surface area, favoring the decomposition of formic acid [91].

Removal of acetone:

Acetone is also called propanone. It is commonly used as a solvent in laboratory and industrial processes. Everyday sources of exposure to acetone include paints, nail polishes and nail polish remover, furniture polish and wallpaper, and common laboratory environments. Xia et al. synthesized porous $\mathrm{Au} / \mathrm{ZnO}$ NPs via facial metal-organic framework route for acetone sensing application [92].

Removal of carbon monoxide:

Carbon monoxide is mostly produced from incomplete combustion of any compounds, from common household burning materials to various petrochemicals. Wang et al. developed $\mathrm{Co}_{3} \mathrm{O}_{4}$ nanoparticles by the pyrolysis of cobalt nitrate in the pores of ZIF-8 ( $\left.\mathrm{Zn}(2 \text {-methylimidazole })_{2}\right)$ for the catalytic oxidation of carbon monoxide. $\mathrm{Co}_{3} \mathrm{O}_{4}$ exhibits good cycling and long-term stability. However, one of the disadvantages of using $\mathrm{Co}_{3} \mathrm{O}_{4}$ is that it suffers from deactivation [93]. Catalytic oxidation of carbon monoxide can also be brought about by $\mathrm{Mn}_{2} \mathrm{O}_{3}$. It has outstanding thermal stability. The efficacy of the catalyst is affected by the presence of moisture, operating temperature, etc. [84].

Removal of toluene:

Toluene is also called methyl benzene. Toluene is a good solvent for non-polar compounds. It is sometimes present in paints and coatings. It is an important compound used as an additive in gasoline. For industrial applications, it is used to prepare nylon, plastics, dyes, inks, and paints. Due to its high level of toxicity, these days, toluene-free inks (marker inks) and paints are more often manufactured.

Toluene can be removed by catalytic oxidation or absorption. Zhao et al. synthesized a series of hollow $\mathrm{Co}_{3} \mathrm{O}_{4}$ polyhedron with different sizes by the pyrolysis of ZIF-67. The 
obtained cobalt-based metal-organic framework owned superior catalytic performance and stability for toluene oxidation [94]. Zhang et al. developed MOF-derived a mesoporous/microporous $\mathrm{Mn}_{2} \mathrm{O}_{3}$ catalyst with a high surface area $\left(141.5 \mathrm{~m}^{2} / \mathrm{g}\right)$ which exhibited excellent catalytic activity for the oxidation of toluene. They also co-related the higher catalytic efficacy with small crystallite size. The manganese oxide sample obtained from different precursors exhibited different catalytic activities for the oxidation of toluene [95]. Wang et al. developed a series of $\mathrm{Zr}$-based catalysts by the direct decomposition of metalorganic framework UiO-66 in air. In this work, CuCeZr catalyst exhibited an excellent oxidation of carbon monoxide and toluene. For the oxidation test, toluene vapor was carried out by pure argon at the rate of $7 \mathrm{~mL} / \mathrm{min}$ in a bubbler followed by diluting with $30 \% \mathrm{O}_{2} / \mathrm{Ar}$ and another pure Ar. Mass flow controller was used to control the gas flow rate. After $30 \mathrm{~min}$, the conversion of toluene was recorded using an online gas chromatogram with a flame ionization detector (FID) and thermal conductivity detector (TCD) [96]. Zhang et al. prepared highly dispersed silver nanoparticles supported on $\mathrm{UiO}-66$ derivative and studied the effect of silver loading on the structure and performance of catalytic oxidation of toluene. Increasing the silver nanoparticles weight up to 10\% (by weight) on UiO-66 caused the collapse of the framework, resulting in the uniform dispersion of silver nanoparticles on the surface. It exhibited an excellent catalytic performance due to higher lattice oxygen and surface silver content. They also unveiled that the catalytic oxidation of toluene led to the formation of benzaldehyde followed by benzoic acid, eventually forming carbon dioxide and water [97].

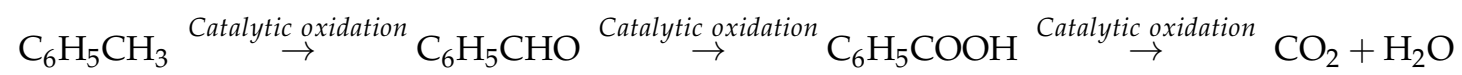

Zhang et al. developed a series of Pd NPs-loaded UiO-66- $\mathrm{NH}_{2}$ using solution impregnation method for the epoxidation of styrene [98].

Removal of xylene:

Xylene vapors are likely to be produced from car tailpipes. $p$-xylene is an isomer of xylene. $p$-xylene is commercially used in the production of polyethylene terephthalate (PET) polymer, beverage bottles, fibers, and films. Separation of p-xylene from its different isomers is of the utmost importance in the petrochemical industry. However, separation is quite difficult by distillation due to their close boiling points (in the range of $138-144{ }^{\circ} \mathrm{C}$ ). However, separation of $\mathrm{p}$-xylene is possible among its isomers by fractional crystallization and adsorption using zeolites. An MOF containing an extended porous network of cyclodextrin and alkali metal salt has been reported for the separation of xylene regioisomers [99].

Removal of styrene:

Liu et al. developed a highly porous silver-nanoparticle-incorporated MOF for the solar-light-triggered regenerative adsorptive removal of styrene [100]. Herein, silver nanoparticle was incorporated with UiO-66 by the colloidal deposition method. UiO-66 is a zirconium-based metal-organic framework with a high surface area $\left(1180-1240 \mathrm{~m}^{2} / \mathrm{g}\right)$ and substantial stability [101]. Here, UiO stands for University of Oslo [12]. The particle size of UiO-66 itself is in the range of 100-500 nm. As-developed Ag/UiO-66 samples were highly porous. The incorporation of Ag NPs increased the styrene adsorption capacity compared to the parent UiO-66. Upon exposure to simulated solar radiation, silver nanoparticles induced the conversion of light energy into thermal energy, which triggers the desorption of styrene from the $\mathrm{Ag} / \mathrm{UiO}-66$. In this way, $\mathrm{Ag} / \mathrm{UiO}-66$ can be regenerated.

Table 2 indicates the MOF-derived nanomaterials applicable in the various VOC gas detection/oxidation. Some nanomaterials fabricated by other methods are also incorporated for a comparative study. 
Table 2. MOF-derived nanomaterials applicable in VOC gas detection or oxidation.

\begin{tabular}{|c|c|c|c|c|c|}
\hline SN & VOCs & Types of Nanomaterials & Efficacy & Preparation Method & Ref. \\
\hline 1 & Acetone & $\mathrm{Au} / \mathrm{ZnO} \mathrm{NPs}$ & $\begin{array}{c}\text { Gas sensing response of } \\
17.1 \mathrm{ppm}^{-1}\end{array}$ & Calcination of ZIF-8 & [92] \\
\hline 3 & Benzene & $\begin{array}{l}\text { ZnO NPs-coated zeolite and } \\
\text { AC }\end{array}$ & Detection limit of $3 \mathrm{ppb}$ & $\begin{array}{c}\text { By coating } \mathrm{ZnO} \text { NPs and } \\
\text { AC on zeolite }\end{array}$ & [52] \\
\hline 4 & Benzene & $\mathrm{MnO}_{2} / \mathrm{ZSM}-5$ zeolite & $\begin{array}{l}\text { Benzene can be removed } \\
\text { completely. } \\
\mathrm{CO}_{2} \text { selectivity reached } \\
\text { to } 84.7 \%\end{array}$ & $\begin{array}{l}\text { Impregnation of metal } \\
\text { oxide on ZSM-5 }\end{array}$ & [102] \\
\hline 6 & $\begin{array}{l}\text { Carbon } \\
\text { monoxide }\end{array}$ & $\mathrm{Co}_{3} \mathrm{O}_{4}$ & - & $\begin{array}{c}\text { Sacrificial removal of } \\
\text { MOFs }\end{array}$ & [93] \\
\hline 7 & $\begin{array}{l}\text { Carbon } \\
\text { monoxide }\end{array}$ & $\begin{array}{l}\text { Mn-MIL-100-derived } \\
\mathrm{Mn}_{2} \mathrm{O}_{3} \text { nonporous }\end{array}$ & - & $\begin{array}{c}\text { Calcination of MOFs at } \\
700^{\circ} \mathrm{C} .\end{array}$ & [84] \\
\hline 9 & Ethanol & $\begin{array}{c}\mathrm{Pd} / \mathrm{SnO}_{2} \mathrm{NPs} \text { on } \\
\text { MOF-derived carbon }\end{array}$ & - & $\begin{array}{c}\text { Microwave-assisted } \\
\text { method }\end{array}$ & [87] \\
\hline 10 & Formaldehyde & $\begin{array}{c}\text { PdO NPs-decorated } \\
\mathrm{ZnO} / \mathrm{ZnCo}_{2} \mathrm{O}_{4} \\
\text { microsphere }\end{array}$ & Detection limit of $0.2 \mathrm{ppm}$ & $\begin{array}{l}\text { Prussian-blue-based } \\
\text { co-precipitation using } \\
\operatorname{MOF}\left(\mathrm{Zn}_{3}\left[\mathrm{Co}(\mathrm{CN})_{6}\right]_{2}\right)\end{array}$ & [89] \\
\hline 11 & Formic acid & $\begin{array}{c}\text { N-doped C-anchored Pd } \\
\text { NPs }\end{array}$ & $\begin{array}{c}\text { Turn over frequency of the } \\
\text { catalyst at } 30^{\circ} \mathrm{C} \text { is } \\
1166 \mathrm{~h}^{-1} \text {. }\end{array}$ & $\begin{array}{l}\text { Wet chemical method } \\
\text { using ZIF-8 }\end{array}$ & [91] \\
\hline 12 & Methanol & $\begin{array}{c}\text { Pt NPs and amorphous Ni } \\
\text { supported } 3 \mathrm{D} \\
\text { mesoporous C }\end{array}$ & $\begin{array}{l}\text { Diverse selectivity on } \\
\text { nitrophenol }\end{array}$ & $\begin{array}{c}\text { Carbonization and } \\
\text { chemical etching of } \\
\text { Cu-MOF }\end{array}$ & [88] \\
\hline 13 & Naphthalene & $\mathrm{CeO}_{2}$ & - & $\begin{array}{c}\text { Homogeneous } \\
\text { precipitation method with } \\
\text { urea }\end{array}$ & [103] \\
\hline 14 & $\begin{array}{l}\text { Propane } \\
\text { Toluene }\end{array}$ & Mesoporous $\alpha-\mathrm{Fe}_{2} \mathrm{O}_{3}$ & - & Wet chemical synthesis & [104] \\
\hline 15 & Propane & Co-BTC & - & Hydrothermal method & [86] \\
\hline 16 & Styrene & $\mathrm{Pd} / \mathrm{UiO}-66-\mathrm{NH}_{2}$ & $\begin{array}{c}\text { Highest conversion }(87 \%) \\
\text { of styrene and best } \\
\text { selectivity }(96.5 \%) \text { in } \\
\text { acetonitrile }\end{array}$ & $\begin{array}{l}\text { Solution impregnation } \\
\text { method }\end{array}$ & [98] \\
\hline 17 & Styrene & $\mathrm{Ag} / \mathrm{UiO}-66$ & - & $\begin{array}{l}\text { Colloidal deposition } \\
\text { method }\end{array}$ & [100] \\
\hline 18 & Toluene & Hierarchical porous carbon & $\begin{array}{l}\text { Adsorption performance of } \\
22290 \mathrm{~m}^{2} / \mathrm{g}\end{array}$ & $\begin{array}{l}\text { Microbial lignocellulose } \\
\text { decomposition }\end{array}$ & [105] \\
\hline 19 & Toluene & $\mathrm{Mn}_{2} \mathrm{O}_{3}$ & - & $\begin{array}{l}\text { Pyrolysis of MOFs } \\
\text { containing Mn salts }\end{array}$ & [95] \\
\hline 20 & Toluene & $\mathrm{Ag} / \mathrm{UiO}-66$ & - & Liquid phase reduction & [97] \\
\hline 21 & Toluene & $\begin{array}{l}\mathrm{MnOx}-\mathrm{CeO}_{2}-\mathrm{MOF} \text { derived } \\
\text { from } \mathrm{MOF}\end{array}$ & - & In situ pyrolysis of MOF-74 & [85] \\
\hline 22 & Toluene & $\begin{array}{c}\text { Hollow } \mathrm{Co}_{3} \mathrm{O}_{4} \text { polyhedral } \\
\text { nanocages }\end{array}$ & $\begin{array}{l}\text { Complete conversion of } \\
\text { toluene was observed at } \\
\qquad 280^{\circ} \mathrm{C}\end{array}$ & Pyrolysis of ZIF-67 MOFs & [94] \\
\hline 23 & $\begin{array}{l}\text { Xylene } \\
\text { isomers }\end{array}$ & $\begin{array}{c}\text { Cyclodextrin-alkali metal } \\
\text { salt MOFs } \\
\text { MIL-101 (Cr) }\end{array}$ & $\begin{array}{c}\text { The equilibrium capacities } \\
\text { of o-xylene, m-xylene and } \\
\text { p-xylene are } 175,70 \text {, and } 64 \\
\text { mg/g, respectively }\end{array}$ & Wet chemical method & [99] \\
\hline 24 & $\begin{array}{l}\text { Toluene and } \\
\text { CO }\end{array}$ & CuCeZr700 & $\begin{array}{c}\text { CuCeZr700 exhibited } 100 \% \\
\text { of CO oxidation at } 140{ }^{\circ} \mathrm{C} \\
\text { and } 90 \% \text { toluene oxidation } \\
\text { at } 310^{\circ} \mathrm{C}\end{array}$ & $\begin{array}{l}\text { Direct decomposition of } \\
\text { UiO-66 MOFs in air }\end{array}$ & [96] \\
\hline
\end{tabular}

\section{Challenges and Future Prospects of MOF-NMs}

The synthesis of hollow-structured materials with a tunable chemical composition sufficient to sense the volatile organic compounds is still a challenging job. These days, 
MOFs of versatile applications are being developed. However, the development of MOFs capable of throughput sensing of volatile organic compounds and their selective removal is still a challenging task. The metal-organic framework consists of metal ions or metal oxide clusters in connection with organic moieties creating a profound surface area with significant structural and chemical diversity. In contrast to the traditional adsorbents, such as activated carbon, activated carbon fiber, silicates, and zeolites, metal-organic frameworkbased nanomaterials (MOF-NMs) have been engineered to tune the adsorption efficacy of volatile organic compounds. Such MOF-NMs are characterized by their tunable pore size and structure, tailorable functionalities, and flexible synthetic methods. A major issue of MOFs is stability, which is largely determined by the structure of metal ions and its nature of bonding with ligands. Weak thermal, chemical, and mechanical stability has limited their use in large-scale applications. The incorporation of nanomaterials has provided some remarkable properties for the MOFs. The incorporation with other functional nanomaterials can greatly improve the sensing performance of MOF [106].

As MOFs act as template for the synthesis of NMs, the design and engineering of an appropriate MOF is a challenging task in the design of MOF-derived NMs. Furthermore, the rampant use of chemicals has absurdly deteriorated the environmental condition as well as health of the researchers, consumers, and allied persons; therefore, the use of green solvents is absolutely necessary. For instance, water and ethanol can be used as green solvents in the synthesis of MOFs.

\section{Conclusions}

With the advent of science and technology, the excessive and rampant use of chemicals cannot be denied. Demand for sophisticated and luxury lifestyles implore the use of high levels of chemicals directly or indirectly in various applications. Many volatile organic compounds are toxic and detrimental to human health and the environment. Such types of volatile organic compounds can be one of the causes of occupational diseases. To be protected from such VOC hazards, there is a significant need to develop a fully satisfactory method for the removal or detoxification of VOCs. Currently, physical, chemical, or biological treatment methods are in action; each method has its own inherent pros and cons, and none of the methods is a panacea. There is an urgent need to devise a promising method for sensing, detoxifying, and removing VOCs. Many cases are not simple, as has been discussed in the literature. A VOC repository may consist of a mixture of various volatile organic compounds rather than some pristine chemicals. Furthermore, a treacherous condition may be found when parts of VOCs are region-selective or stereo-selective. In the chaos of the complex nature and diversity of VOCs, it is hard to find a simple and holistic method for the removal of VOCs at single slot. In this context, to improve the indoor as well as environmental air quality, it is necessary to innovate an efficient, smart, and facile approach for the removal of VOCs. Low-cost, highly efficient, tunable, tailorable, and environmentally friendly nanomaterials with high stability must be assessed by rigorous research. Materials such as carbon-based, metal-oxide-based materials and their variants with promising morphologies, synthesis techniques, and nanoarchitechtonics are needed for the removal of VOCs. In this context, special attention is to be paid to the minimization of VOCs, as well as the removal and detoxification of them.

Author Contributions: Conceptualization, D.P.B.; methodology, D.P.B.; software, D.P.B., J.A. and B.P.; validation, M.P. and G.P.O.; formal analysis, J.A. and B.P.; investigation, M.P. and G.P.O.; resources, M.P.; data curation, D.P.B. and G.P.O.; writing—original draft preparation, D.P.B.; writing-review and editing, D.P.B., B.P. and G.P.O.; visualization, G.P.O.; supervision, M.P.; project administration, M.P.; funding acquisition, M.P. and G.P.O. All authors have read and agreed to the published version of the manuscript.

Funding: This research was funded by National Research Foundation of Korea, grant number 2020R1I1A101068856 and 2018M3C1B5052283. 
Acknowledgments: The authors are grateful to the Basic Science Research Program through the National Research Foundation of Korea (NRF) sponsored by the Ministry of Education (NRF Grant Number: 2020R1I1A101068856) and Traditional Culture Convergence Program through the National Research Foundation of Korea (NRF) sponsored by the ministry of Science, ICT\& Future planning (Grant number: 2018M3C1B5052283).

Conflicts of Interest: The authors declare no conflict of interest.

$\begin{array}{ll}\text { Abbreviations } \\ \text { BDC } & \text { 1:4-Benzenedicarboxylate } \\ \text { BTC } & \text { 1,3,5-benzenetricarboxylic acid } \\ \text { BTEX } & \text { Benzene, toluene, ethylbenzene, and xylene } \\ \text { COF } & \text { Covalent organic framework } \\ \text { DDT } & \text { Dichlorodiphenyl trichloroethane } \\ \text { EPA } & \text { Environmental Protection Agency } \\ \text { FID } & \text { Flame ionization detector } \\ \text { LFSE } & \text { Ligand field stabilization energy } \\ \text { MOF } & \text { Metal-organic framework } \\ \text { PAH } & \text { Polycyclic aromatic hydrocarbons } \\ \text { PBB } & \text { Polybrominated biphenyl } \\ \text { PCB } & \text { Polychlorinated biphenyl } \\ \text { PCPs } & \text { Porous coordination polymer } \\ \text { PET } & \text { Polyethylene terephthalate } \\ \text { PM } & \text { Particulate matter } \\ \text { PVC } & \text { Polyvinyl chloride } \\ \text { ROS } & \text { Reactive oxygen species } \\ \text { SOA } & \text { Secondary organic aerosol } \\ \text { SVOC } & \text { Semi-volatile organic compounds } \\ \text { TCD } & \text { Thermal conductivity detector } \\ \text { UiO } & \text { University of Oslo } \\ \text { VOC } & \text { Volatile organic compound } \\ \text { VVOC } & \text { Very volatile organic compounds } \\ \text { WHO } & \text { World Health Organization } \\ \text { ZIF } & \text { Zeolite imidazolate framework } \\ \text { ZIF-8 } & \text { Zn(2-methylimidazole) } 2 \\ & \end{array}$

\section{References}

1. Lin, Y.; Wan, H.; Wu, D.; Chen, G.; Zhang, N.; Liu, X.; Li, J.; Cao, Y.; Qiu, G.; Ma, R. Metal-organic framework hexagonal nanoplates: Bottom-up synthesis, topotactic transformation, and efficient oxygen evolution reaction. J. Am. Chem. Soc. 2020, 142, 7317-7321. [CrossRef]

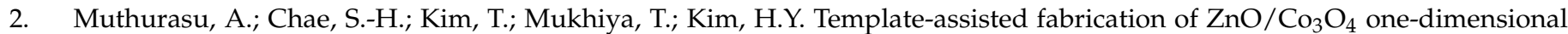
metal-organic framework array decorated with amorphous iron oxide/hydroxide nanoparticles as an efficient electrocatalyst for the oxygen evolution reaction. Energy Fuels 2020, 34, 7716-7725. [CrossRef]

3. Rao, K.P.; Higuchi, M.; Duan, J.; Kitagawa, S. pH-dependent interpenetrated, polymorphic, Cd ${ }^{2+}-$ and BTB-based porous coordination polymers with open metal sites. Cryst. Growth Des. 2013, 13, 981-985. [CrossRef]

4. He, C.-T.; Tian, J.-Y.; Liu, S.-Y.; Ouyang, G.; Zhang, J.-P.; Chen, X.-M. A porous coordination framework for highly sensitive and selective solid-phase microextraction of non-polar volatile organic compounds. Chem. Sci. 2013, 4, 351-356. [CrossRef]

5. Peng, L.; Wu, S.; Yang, X.; Hu, J.; Fu, X.; Li, M.; Bai, L.; Huo, Q.; Guan, J. Oxidation of benzyl alcohol over metal organic frameworks M-BTC (M = Co, Cu, Fe). New J. Chem. 2017, 41, 2891-2894. [CrossRef]

6. Ye, Y.; Guo, W.; Wang, L.; Lihua, W.; Song, Z.; Chen, J.; Zhang, Z.; Xiang, S.; Chen, B. Straightforward loading of imidazole molecules into metal-organic framework for high proton conduction. J. Am. Chem. Soc. 2017, 139, 15604-15607. [CrossRef] [PubMed]

7. Schaate, A.; Dühnen, S.; Platz, G.; Lilienthal, S.; Schneider, A.M.; Behrens, P. A Novel Zr-based porous coordination polymer containing azobenzenedicarboxylate as a linker. Eur. J. Inorg. Chem. 2012, 2012, 790-796. [CrossRef]

8. Cheng, Y.; Xiao, X.; Guo, X.; Yao, H.; Pang, H. Synthesis of "Quasi-Ce-MOF" electrocatalysts for enhanced urea oxidation reaction performance. ACS Sustain. Chem. Eng. 2020, 8, 8675-8680. [CrossRef]

9. Li, Y.; Shan, Y.; Pang, H. Design and synthesis of nitrogen-doped hexagonal NiCoO nanoplates derived from Ni-Co-MOF for high-performance electrochemical energy storage. Chin. Chem. Lett. 2020, 31, 2280-2286. [CrossRef] 
10. Liang, Z.; Zhao, R.; Qiu, T.; Zou, R.; Xu, Q. Metal-organic framework-derived materials for electrochemical energy applications. Energy Chem. 2019, 1, 100001. [CrossRef]

11. Li, D.; Xu, H.-Q.; Jiao, L.; Jiang, H.-L. Metal-organic frameworks for catalysis: State of the art, challenges, and opportunities. Energy Chem. 2019, 1, 100005. [CrossRef]

12. He, Y.; Wang, Z.; Wang, H.; Wang, Z.; Zeng, G.; Xu, P.; Huang, D.; Chen, M.; Song, B.; Qin, H.; et al. Metal-organic frameworkderived nanomaterials in environment related fields: Fundamentals, properties and applications. Coord. Chem. Rev. 2020, 213618. [CrossRef]

13. Zhang, Y.; Yuan, S.; Feng, X.; Li, H.; Zhou, J.; Wang, B. Preparation of nanofibrous metal-organic framework filters for efficient air pollution control. J. Am. Chem. Soc. 2016, 138, 5785-5788. [CrossRef] [PubMed]

14. Furukawa, H.; Cordova, K.E.; O'Keeffe, M.; Yaghi, O.M. The chemistry and applications of metal-organic frameworks. Science 2013, 341, 1230444. [CrossRef]

15. Yang, W.; Li, X.; Li, Y.; Zhu, R.; Pang, H. Applications of metal-organic-framework-derived carbon materials. Adv. Mater. 2019, 31, 1804740. [CrossRef]

16. Min, H.; Wang, J.; Qi, Y.; Zhang, Y.; Han, X.; Xu, Y.; Xu, J.; Li, Y.; Chen, L.; Cheng, K.; et al. Biomimetic metal-organic framework nanoparticles for cooperative combination of antiangiogenesis and photodynamic therapy for enhanced efficacy. Adv. Mater. 2019, 31, 1808200. [CrossRef] [PubMed]

17. Peera, S.; Koutavarapu, R.; Liu, C.; Rajeshkhanna, G.; Asokan, A.; Reddy, C. Cobalt nanoparticle-embedded nitrogen-doped carbon catalyst derived from a solid-state metal-organic framework complex for OER and HER electrocatalysis. Energies 2021, 14, 1320. [CrossRef]

18. Salunkhe, R.; Kaneti, Y.; Yamauchi, Y. Metal-organic framework-derived nanoporous metal oxides toward supercapacitor applications: Progress and prospects. ACS Nano 2017, 11, 5293-5308. [CrossRef]

19. Ojha, G.P.; Muthurasu, A.; Tiwari, A.P.; Pant, B.; Chhetri, K.; Mukhiya, T.; Dahal, B.; Lee, M.; Park, M.; Kim, H.-Y. Vapor solid phase grown hierarchical CuxO NWs integrated MOFs-derived $\mathrm{CoS}_{2}$ electrode for high-performance asymmetric supercapacitors and the oxygen evolution reaction. Chem. Eng. J. 2020, 399, 125532. [CrossRef]

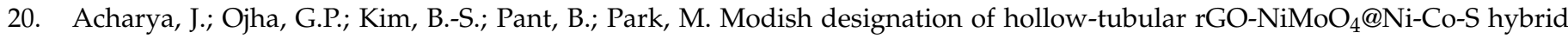
core-shell electrodes with multichannel superconductive pathways for high-performance asymmetric supercapacitors. ACS Appl. Mater. Interfaces 2021, 13, 17487-17500. [CrossRef]

21. Acharya, J.; Ko, T.H.; Seo, M.-K.; Khil, M.-S.; Kim, H.-Y.; Kim, B.-S. Engineering the hierarchical heterostructures of Zn-Ni-Co nanoneedles Arrays@Co-Ni-LDH nanosheets core-sheath electrodes for a hybrid asymmetric supercapacitor with high energy density and excellent cyclic stability. ACS Appl. Energy Mater. 2020, 3, 7383-7396. [CrossRef]

22. Acharya, J.; Pant, B.; Ojha, G.P.; Kong, H.-S.; Park, M. Engineering triangular bimetallic metal-organic-frameworks derived hierarchical zinc-nickel-cobalt oxide nanosheet arrays@reduced graphene oxide-Ni foam as a binder-free electrode for ultra-high rate performance supercapacitors and methanol electro-oxidation. J. Colloid Interface Sci. 2021, 602, 573-589. [CrossRef] [PubMed]

23. Li, H.; Eddaoudi, M.; O'Keeffe, M.; Yaghi, O. Design and synthesis of an exceptionally stable and highly porous metal-organic framework. Nature 1999, 402, 276-279. [CrossRef]

24. Kumar, V.; Lee, Y.-S.; Shin, J.-W.; Kim, K.-H.; Kukkar, D.; Tsang, Y.F. Potential applications of graphene-based nanomaterials as adsorbent for removal of volatile organic compounds. Environ. Int. 2020, 135, 105356. [CrossRef]

25. Zhao, Q.; Liu, Q.; Zheng, Y.; Han, R.; Song, C.; Ji, N.; Ma, D. Enhanced catalytic performance for volatile organic compound oxidation over in-situ growth of $\mathrm{MnOx}_{0} \mathrm{Co}_{3} \mathrm{O}_{4}$ nanowire. Chemosphere 2020, 244, 125532. [CrossRef] [PubMed]

26. Lewis, A.C.; Hopkins, J.R.; Carslaw, D.C.; Hamilton, J.F.; Nelson, B.S.; Stewart, G.; Dernie, J.; Passant, N.; Murrells, T. An increasing role for solvent emissions and implications for future measurements of volatile organic compounds. Philos. Trans. $R$. Soc. A Math. Phys. Eng. Sci. 2020, 378, 20190328. [CrossRef] [PubMed]

27. Saini, V.K.; Pires, J. Development of metal organic framework-199 immobilized zeolite foam for adsorption of common indoor VOCs. J. Environ. Sci. 2017, 55, 321-330. [CrossRef]

28. Jackson, S.; Rananaware, A.; Rix, C.; Bhosale, S.V.; Latham, K. Highly fluorescent metal-organic framework for the sensing of volatile organic compounds. Cryst. Growth Des. 2016, 16, 3067-3071. [CrossRef]

29. Kandiah, M.; Usseglio, S.; Svelle, S.; Olsbye, U.; Lillerud, K.P.; Tilset, M. Post-synthetic modification of the metal-organic framework compound UiO-66. J. Mater. Chem. 2010, 20, 9848-9851. [CrossRef]

30. Bari, M.A.; Kindzierski, W.B.; Wheeler, A.J.; Héroux, M.Ė.; Wallace, L.A. Source apportionment of indoor and outdoor volatile organic compounds at homes in Edmonton, Canada. Build. Environ. 2015, 90, 114-124. [CrossRef]

31. Contarino, R.; Brighina, S.; Fallico, B.; Cirvilleri, G.; Parafati, L.; Restuccia, C. Volatile organic compounds (VOCs) produced by biocontrol yeasts. Food Microbiol. 2019, 82, 70-74. [CrossRef]

32. Weisskopf, L.; Schulz, S.; Garbeva, P. Microbial volatile organic compounds in intra-kingdom and inter-kingdom interactions Nat. Rev. Microbiol. 2021, 19, 391-404. [CrossRef] [PubMed]

33. Guha, P.; Nandi, S. Essential oil of betel leaf (Piper betle L.): A novel addition to the world food sector. In Essential Oil Research; Springer: Cham, Switzerland, 2019; pp. 149-196.

34. Zhigzhitzhapova, S.V.; Radnaeva, L.D.; Gao, Q.; Chen, S.; Zhang, F. Chemical composition of volatile organic compounds of Artemisia vulgaris L. (Asteraceae) from the Qinghai-Tibet Plateau. Ind. Crop. Prod. 2016, 83, 462-469. [CrossRef] 
35. Liu, Y.; Song, M.; Liu, X.; Zhang, Y.; Hui, L.; Kong, L.; Zhang, Y.; Zhang, C.; Qu, Y.; An, J.; et al. Characterization and sources of volatile organic compounds (VOCs) and their related changes during ozone pollution days in 2016 in Beijing, China. Environ. Pollut. 2020, 257, 113599. [CrossRef] [PubMed]

36. Zheng, H.; Kong, S.; Yan, Y.; Chen, N.; Yao, L.; Liu, X.; Wu, F.; Cheng, Y.; Niu, Z.; Zheng, S.; et al. Compositions, sources and health risks of ambient volatile organic compounds (VOCs) at a petrochemical industrial park along the Yangtze River. Sci. Total Environ. 2020, 703, 135505. [CrossRef]

37. Arı, A.; Arı, P.E.; Yenisoy-Karakaş, S.; Gaga, E.O. Source characterization and risk assessment of occupational exposure to volatile organic compounds (VOCs) in a barbecue restaurant. Build. Environ. 2020, 174, 106791. [CrossRef]

38. Liu, R.; Chen, J.; Li, G.; Wang, X.; An, T. Cutting down on the ozone and SOA formation as well as health risks of VOCs emitted from e-waste dismantlement by integration technique. J. Environ. Manag. 2019, 249. [CrossRef]

39. Aklilu, Y.-A.; Cho, S.; Zhang, Q.; Taylor, E. Source apportionment of volatile organic compounds measured near a cold heavy oil production area. Atmos. Res. 2018, 206, 75-86. [CrossRef]

40. Wei, W.; Cheng, S.; Li, G.; Wang, G.; Wang, H. Characteristics of volatile organic compounds (VOCs) emitted from a petroleum refinery in Beijing, China. Atmos. Environ. 2014, 89, 358-366. [CrossRef]

41. Sahu, L.K.; Yadav, R.; Pal, D. Source identification of VOCs at an urban site of western India: Effect of marathon events and anthropogenic emissions. J. Geophys. Res. Atmos. 2016, 121, 2416-2433. [CrossRef]

42. Semenya, K.; Machete, F. Influence of kitchen structures on household exposure to firewood-induced volatile organic compounds in Senwabarwana villages. Air Qual. Atmos. Health 2020, 13, 1193-1201. [CrossRef]

43. Zhang, K.; Li, L.; Huang, L.; Wang, Y.; Huo, J.; Duan, Y.; Wang, Y.; Fu, Q. The impact of volatile organic compounds on ozone formation in the suburban area of Shanghai. Atmos. Environ. 2020, 232, 117511. [CrossRef]

44. Gironi, F.; Piemonte, V. VOCs removal from dilute vapour streams by adsorption onto activated carbon. Chem. Eng. J. 2011, 172, 671-677. [CrossRef]

45. Li, L.; Liu, S.; Liu, J. Surface modification of coconut shell based activated carbon for the improvement of hydrophobic VOC removal. J. Hazard. Mater. 2011, 192, 683-690. [CrossRef]

46. Cheng, J.; Li, L.; Li, Y.; Wang, Q.; He, C. Fabrication of pillar(5)arene-polymer-functionalized cotton fibers as adsorbents for adsorption of organic pollutants in water and volatile organic compounds in air. Cellulose 2019, 26, 3299-3312. [CrossRef]

47. Awasthi, G.P.; Bhattarai, D.P.; Maharjan, B.; Kim, K.-S.; Park, C.H.; Kim, C.S. Synthesis and characterizations of activated carbon from Wisteria sinensis seeds biomass for energy storage applications. J. Ind. Eng. Chem. 2019, 72, 265-272. [CrossRef]

48. Bhattarai, D.P.; Pokharel, P.; Xiao, D. Surface functionalization of polymers. In Reactive and Functional Polymers; Springer: New York, NY, USA, 2020; Volume 4, pp. 5-34.

49. Wang, H.; Sun, Y.; Zhu, T.; Wang, W.; Deng, H. Adsorption of acetaldehyde onto carbide-derived carbon modified by oxidation. Chem. Eng. J. 2015, 273, 580-587. [CrossRef]

50. Zhuang, Z.; Wang, L.; Tang, J. Efficient removal of volatile organic compound by ball-milled biochars from different preparing conditions. J. Hazard. Mater. 2021, 406, 124676. [CrossRef]

51. Kansal, A. Sources and reactivity of NMHCs and VOCs in the atmosphere: A review. J. Hazard. Mater. 2009, 166, 17-26. [CrossRef]

52. Changsuphan, A.; Wahab, M.I.B.; Oanh, N.T.K. Removal of benzene by ZnO nanoparticles coated on porous adsorbents in presence of ozone and UV. Chem. Eng. J. 2012, 181-182, 215-221. [CrossRef]

53. Lemus, J.; Martinez, M.M.; Palomar, J.F.; Gomez-Sainero, L.; Gilarranz, M.A.; Rodríguez, J.J. Removal of chlorinated organic volatile compounds by gas phase adsorption with activated carbon. Chem. Eng. J. 2012, 211, 246-254. [CrossRef]

54. Xin, Y.; Ando, Y.; Nakagawa, S.; Nishikawa, H.; Shirai, T. New possibility of hydroxyapatites as noble-metal-free catalysts towards complete decomposition of volatile organic compounds. Catal. Sci. Technol. 2020, 10, 5453-5459. [CrossRef]

55. Li, J.; Chen, R.; Cui, W.; Dong, X.; Wang, H.; Kim, K.-H.; Chu, Y.; Sheng, J.; Sun, Y.; Dong, F. Synergistic photocatalytic decomposition of a volatile organic compound mixture: High efficiency, reaction mechanism, and long-term stability. ACS Catal. 2020, 10, 7230-7239. [CrossRef]

56. Debono, O.; Thevenet, F.; Gravejat, P.; Hequet, V.; Raillard, C.; LE Coq, L.; Locoge, N. Toluene photocatalytic oxidation at ppbv levels: Kinetic investigation and carbon balance determination. Appl. Catal. B Environ. 2011, 106, 600-608. [CrossRef]

57. Yang, X.; Ma, X.; Han, D.; Xiao, M.; Ma, L.; Sun, H.; Yu, X.; Ge, M. Efficient removal of toluene over palladium supported on hierarchical alumina microspheres catalyst. Catal. Today 2020, 375, 352-359. [CrossRef]

58. Li, P.; Kim, S.; Jin, J.; Do, H.C.; Park, J.H. Efficient photodegradation of volatile organic compounds by iron-based metal-organic frameworks with high adsorption capacity. Appl. Catal. B Environ. 2020, 263, 118284. [CrossRef]

59. Yu, G.; Mu, M.; Li, J.; Wu, B.; Xu, R.; Liu, N.; Chen, B.; Dai, C. Imidazolium-based ionic liquids introduced into $\pi$-electron donors: Highly efficient toluene capture. ACS Sustain. Chem. Eng. 2020, 8, 9058-9069. [CrossRef]

60. Higashimoto, S.; Katsuura, K.; Yamamoto, M.; Takahashi, M. Photocatalytic activity for decomposition of volatile organic compound on $\mathrm{Pt}_{-} \mathrm{WO}_{3}$ enhanced by simple physical mixing with $\mathrm{TiO}_{2}$. Catal. Commun. 2020, 133, 105831. [CrossRef]

61. Almomani, F.; Bhosale, R.; Shawaqfah, M. Solar oxidation of toluene over Co doped nano-catalyst. Chemosphere 2020, $255,126878$. [CrossRef]

62. Boudjema, L.; Long, J.; Petitjean, H.; Larionova, J.; Guari, Y.; Trens, P.; Salles, F. Adsorption of volatile organic compounds by ZIF-8, Cu-BTC and a Prussian blue analogue: A comparative study. Inorg. Chim. Acta 2020, 501, 119316. [CrossRef] 
63. Tu, M.; Wannapaiboon, S.; Khaletskaya, K.; Fischer, R.A. Engineering zeolitic-imidazolate framework (ZIF) thin film devices for selective detection of volatile organic compounds. Adv. Funct. Mater. 2015, 25, 4470-4479. [CrossRef]

64. Maharjan, B.; Kumar, D.; Awasthi, G.P.; Bhattarai, D.P.; Kim, J.Y.; Park, C.H.; Kim, C.S. Synthesis and characterization of gold/silica hybrid nanoparticles incorporated gelatin methacrylate conductive hydrogels for H9C2 cardiac cell compatibility study. Compos. Part B Eng. 2019, 177, 107415. [CrossRef]

65. Bhattarai, D.P.; Kim, B.S. NIR-triggered hyperthermal effect of polythiophene nanoparticles synthesized by surfactant-free oxidative polymerization method on colorectal carcinoma cells. Cells 2020, 9, 2122. [CrossRef] [PubMed]

66. Rezk, A.I.; Bhattarai, D.P.; Park, J.; Park, C.H.; Kim, C.S. Polyaniline-coated titanium oxide nanoparticles and simvastatin-loaded poly( $\varepsilon$-caprolactone) composite nanofibers scaffold for bone tissue regeneration application. Colloids Surf. B Biointerfaces $\mathbf{2 0 2 0}$ 192, 111007. [CrossRef]

67. Nathanael, A.J.; Kannaiyan, K.; Kunhiraman, A.K.; Kumaravel, V. 8-Nanomaterials for detection and removal of gases. In Nanomaterials for Sustainable Energy and Environmental Remediation; Naushad, M., Saravanan, R., Raju, K., Eds.; Elsevier: Amsterdam, The Netherlands, 2020; pp. 219-260.

68. Law, T.S.C.; Chao, C.; Chan, G.Y.W.; Law, A.K.Y. Confined catalytic oxidation of volatile organic compounds by transition metal containing zeolites and ionizer. Atmos. Environ. 2003, 37, 5433-5437. [CrossRef]

69. Lamonier, J.-F.; Boutoundou, A.-B.; Gennequin, C.; Pérez-Zurita, M.J.; Siffert, S.; Aboukais, A. Catalytic removal of toluene in air over Co-Mn-Al nano-oxides synthesized by hydrotalcite route. Catal. Lett. 2007, 118, 165-172. [CrossRef]

70. Attia, M.F.; Swasy, M.I.; Ateia, M.; Alexis, F.; Whitehead, D.C. Periodic mesoporous organosilica nanomaterials for rapid capture of VOCs. Chem. Commun. 2020, 56, 607-610. [CrossRef] [PubMed]

71. Kumar, M.; Xiong, X.; Wan, Z.; Sun, Y.; Tsang, D.C.; Gupta, J.; Gao, B.; Cao, X.; Tang, J.; Ok, Y.S. Ball milling as a mechanochemical technology for fabrication of novel biochar nanomaterials. Bioresour. Technol. 2020, 312, 123613. [CrossRef]

72. Kumar, A.; Singh, E.; Khapre, A.; Bordoloi, N.; Kumar, S. Sorption of volatile organic compounds on non-activated biochar. Bioresour. Technol. 2020, 297, 122469. [CrossRef] [PubMed]

73. Rajabi, H.; Mosleh, M.H.; Mandal, P.; Lea-Langton, A.; Sedighi, M. Sorption behaviour of xylene isomers on biochar from a range of feedstock. Chemosphere 2021, 268, 129310. [CrossRef]

74. Bhattarai, D.P.; Awasthi, G.P.; Maharjan, B.; Lee, J.; Kim, B.-S.; Park, C.H.; Kim, C.S. Synthesis of polythiophene nanoparticles by surfactant-free chemical oxidative polymerization method: Characterization, in vitro biomineralization, and cytotoxicity evaluation. J. Ind. Eng. Chem. 2019, 77, 243-252. [CrossRef]

75. Bhattarai, D.P.; Shrestha, S.; Shrestha, B.K.; Park, C.H.; Kim, C.S. A controlled surface geometry of polyaniline doped titania nanotubes biointerface for accelerating MC3T3-E1 cells growth in bone tissue engineering. Chem. Eng. J. 2018, 350, 57-68. [CrossRef]

76. Bhattarai, D.P.; Tiwari, A.P.; Maharjan, B.; Tumurbaatar, B.; Park, C.H.; Kim, C.S. Sacrificial template-based synthetic approach of polypyrrole hollow fibers for photothermal therapy. J. Colloid Interface Sci. 2019, 534, 447-458. [CrossRef]

77. Bhattarai, D.P.; Kim, M.H.; Park, H.; Park, W.H.; Kim, B.S.; Kim, C.S. Coaxially fabricated polylactic acid electrospun nanofibrous scaffold for sequential release of tauroursodeoxycholic acid and bone morphogenic protein2 to stimulate angiogenesis and bone regeneration. Chem. Eng. J. 2020, 389, 123470. [CrossRef]

78. Bhattarai, D.P.; Hwang, T.I.; Kim, J.I.; Lee, J.H.; Chun, S.; Kim, B.-S.; Park, C.H.; Kim, C.S. Synthesis of polypyrrole nanorods via sacrificial removal of aluminum oxide nanopore template: A study on cell viability, electrical stimulation and neuronal differentiation of PC12 cells. Mater. Sci. Eng. C 2020, 107, 110325. [CrossRef] [PubMed]

79. Maharjan, B.; Kaliannagounder, V.K.; Jang, S.R.; Awasthi, G.P.; Bhattarai, D.P.; Choukrani, G.; Park, C.H.; Kim, C.S. In-situ polymerized polypyrrole nanoparticles immobilized poly( $\varepsilon$-caprolactone) electrospun conductive scaffolds for bone tissue engineering. Mater. Sci. Eng. C 2020, 114, 111056. [CrossRef]

80. Cho, W.; Park, S.; Oh, M. Coordination polymer nanorods of Fe-MIL-88B and their utilization for selective preparation of hematite and magnetite nanorods. Chem. Commun. 2011, 47, 4138-4140. [CrossRef] [PubMed]

81. Liu, B.; Zhang, X.; Shioyama, H.; Mukai, T.; Sakai, T.; Xu, Q. Converting cobalt oxide subunits in cobalt metal-organic framework into agglomerated $\mathrm{Co}_{3} \mathrm{O}_{4}$ nanoparticles as an electrode material for lithium ion battery. J. Power Sources 2010, 195, 857-861. [CrossRef]

82. Jiang, H.-L.; Liu, B.; Lan, Y.-Q.; Kuratani, K.; Akita, T.; Shioyama, H.; Zong, F.; Xu, Q. From metal-organic framework to nanoporous carbon: Toward a very high surface area and hydrogen uptake. J. Am. Chem. Soc. 2011, 133, 11854-11857. [CrossRef]

83. Kaneti, Y.; Tang, J.; Salunkhe, R.; Jiang, X.; Yu, A.; Wu, K.C.-W.; Yamauchi, Y. Nanoarchitectured design of porous materials and nanocomposites from metal-organic frameworks. Adv. Mater. 2017, 29, 1604898. [CrossRef]

84. Zhang, X.; Li, H.; Hou, F.; Yang, Y.; Dong, H.; Liu, N.; Wang, Y.; Cui, L. Synthesis of highly efficient $\mathrm{Mn}_{2} \mathrm{O}_{3}$ catalysts for CO oxidation derived from Mn-MIL-100. Appl. Surf. Sci. 2017, 411, 27-33. [CrossRef]

85. Sun, H.; Yu, X.; Ma, X.; Yang, X.; Lin, M.; Ge, M. MnOx-CeO 2 catalyst derived from metal-organic frameworks for toluene oxidation. Catal. Today 2020, 355, 580-586. [CrossRef]

86. Lin, D.; Zheng, Y.; Feng, X.; You, Y.; Wu, E.; Luo, Y.; Qian, Q.; Chen, Q. Highly stable $\mathrm{Co}_{3} \mathrm{O}_{4}$ nanoparticles-assembled microrods derived from MOF for efficient total propane oxidation. J. Mater. Sci. 2020, 55, 5190-5202. [CrossRef]

87. Ipadeola, A.K.; Barik, R.; Ray, S.C.; Ozoemena, K.I. Bimetallic $\mathrm{Pd} / \mathrm{SnO}_{2}$ nanoparticles on metal organic framework (MOF)-derived carbon as electrocatalysts for ethanol oxidation. Electrocatalysis 2019, 10, 366-380. [CrossRef] 
88. Wu, X.-Q.; Zhao, J.; Wu, Y.-P.; Dong, W.-W.; Li, D.-S.; Li, J.-R.; Zhang, Q. Ultrafine Pt nanoparticles and amorphous nickel supported on 3D mesoporous carbon derived from cu-metal-organic framework for efficient methanol oxidation and nitrophenol reduction. ACS Appl. Mater. Interfaces 2018, 10, 12740-12749. [CrossRef]

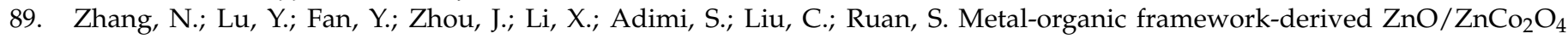
microspheres modified by catalytic PdO nanoparticles for sub-ppm-level formaldehyde detection. Sens. Actuators B Chem. 2020, 315, 128118. [CrossRef]

90. Wang, D.; Li, Z.; Zhou, J.; Fang, H.; He, X.; Jena, P.; Zeng, J.-B.; Wang, W.-N. Simultaneous detection and removal of formaldehyde at room temperature: Janus Au@ZnO@ZIF-8 nanoparticles. Nano Micro Lett. 2017, 10, 4. [CrossRef]

91. Wang, X.; Meng, Q.; Gao, L.; Liu, J.; Ge, J.; Liu, C.; Xing, W. Metal organic framework derived nitrogen-doped carbon anchored palladium nanoparticles for ambient temperature formic acid decomposition. Int. J. Hydrog. Energy 2019, 44, 28402-28408. [CrossRef]

92. Xia, J.; Diao, K.; Zheng, Z.; Cui, X. Porous Au/ZnO nanoparticles synthesised through a metal organic framework (MOF) route for enhanced acetone gas-sensing. RSC Adv. 2017, 7, 38444-38451. [CrossRef]

93. Wang, W.; Li, Y.; Zhang, R.; He, D.; Liu, H.; Liao, S. Metal-organic framework as a host for synthesis of nanoscale $\mathrm{Co}_{3} \mathrm{O}_{4}$ as an active catalyst for CO oxidation. Catal. Commun. 2011, 12, 875-879. [CrossRef]

94. Zhao, J.; Tang, Z.; Dong, F.; Zhang, J. Controlled porous hollow $\mathrm{Co}_{3} \mathrm{O}_{4}$ polyhedral nanocages derived from metal-organic frameworks (MOFs) for toluene catalytic oxidation. Mol. Catal. 2019, 463, 77-86. [CrossRef]

95. Zhang, X.; Lv, X.; Bi, F.; Lu, G.; Wang, Y. Highly efficient $\mathrm{Mn}_{2} \mathrm{O}_{3}$ catalysts derived from Mn-MOFs for toluene oxidation: The influence of MOFs precursors. Mol. Catal. 2020, 482, 110701. [CrossRef]

96. Wang, L.; Yin, G.; Yang, Y.; Zhang, X. Enhanced CO oxidation and toluene oxidation on CuCeZr catalysts derived from UiO-66 metal organic frameworks. React. Kinet. Mech. Catal. 2019, 128, 193-204. [CrossRef]

97. Zhang, X.; Song, L.; Bi, F.; Zhang, D.; Wang, Y.; Cui, L. Catalytic oxidation of toluene using a facile synthesized Ag nanoparticle supported on UiO-66 derivative. J. Colloid Interface Sci. 2020, 571, 38-47. [CrossRef] [PubMed]

98. Zhang, Y.; Li, Y.-X.; Liu, L.; Han, Z.-B. Palladium nanoparticles supported on UiO-66- $\mathrm{NH}_{2}$ as heterogeneous catalyst for epoxidation of styrene. Inorg. Chem. Commun. 2019, 100, 51-55. [CrossRef]

99. Chen, L.; Zhu, D.-D.; Ji, G.-J.; Yuan, S.; Qian, J.-F.; He, M.-Y.; Chen, Q.; Zhang, Z.-H. Efficient adsorption separation of xylene isomers using a facilely fabricated cyclodextrin-based metal-organic framework. J. Chem. Technol. Biotechnol. 2018, 93, $2898-2905$. [CrossRef]

100. Liu, H.; Xu, M.; Li, G.; Zhang, W.; An, T. Solar-light-triggered regenerative adsorption removal of styrene by silver nanoparticles incorporated in metal-organic frameworks. Environ. Sci. Nano 2021, 8, 543-553. [CrossRef]

101. Cavka, J.H.; Jakobsen, S.; Olsbye, U.; Guillou, N.; Lamberti, C.; Bordiga, S.; Lillerud, K.P. A new zirconium inorganic building brick forming metal organic frameworks with exceptional stability. J. Am. Chem. Soc. 2008, 130, 13850-13851. [CrossRef]

102. Huang, H.; Huang, W.; Xu, Y.; Ye, X.; Wu, M.; Shao, Q.; Ou, G.; Peng, Z.; Shi, J.; Chen, J.; et al. Catalytic oxidation of gaseous benzene with ozone over zeolite-supported metal oxide nanoparticles at room temperature. Catal. Today 2015, 258, 627-633. [CrossRef]

103. García, T.; Solsona, B.; Taylor, S.H. Naphthalene total oxidation over metal oxide catalysts. Appl. Catal. B Environ. 2006, 66, 92-99. [CrossRef]

104. Solsona, B.; García, T.; Sanchis, R.; Soriano, M.D.; Moreno, M.; Rodríguez-Castellón, E.; Agouram, S.; Dejoz, A.; Nieto, J.M.L. Total oxidation of VOCs on mesoporous iron oxide catalysts: Soft chemistry route versus hard template method. Chem. Eng. J. 2016, 290, 273-281. [CrossRef]

105. Zhang, W.; Cheng, H.; Niu, Q.; Fu, M.; Huang, H.; Ye, D. Microbial targeted degradation pretreatment: A novel approach to preparation of activated carbon with specific hierarchical porous structures, high surface areas, and satisfactory toluene adsorption performance. Environ. Sci. Technol. 2019, 53, 7632-7640. [CrossRef] [PubMed]

106. Fang, X.; Zong, B.; Mao, S. Metal-organic framework-based sensors for environmental contaminant sensing. Nano Micro Lett. 2018, 10, 1-19. [CrossRef] [PubMed] 